\title{
INDONESIA MARITIME INFORMATION CENTER STRATEGY IN DEALING WITH INFORMATION WAREFARE IN INDONESIA'S SEA AREA
}

\author{
Bagus T. I Gede ${ }^{\star}$, Mohammad Fadli \\ University of Brawijaya, Malang, Indonesia \\ *E-mail:tiang.gede@gmail.com
}

\begin{abstract}
The development of information fosters confidence for many parties that war will be changed profoundly and permanently by using digital instruments. The term information warfare, which refers to information systems such as computers, communication networks, and databases, which are generally used for military purposes, is transformed into a form of war without casualties that have the scope of command and control over information. This study aims to analyze and explore IMIC's ability to provide comprehensive maritime information and review IMIC's strategy in dealing with the threat of information warfare to realize national security for Indonesia. By applying a qualitative research method with an explanatory approach, the results of this study indicate that the IMIC strategy has the ultimate goal of improving national security through procedures for action that prioritize integration in gathering Information about Indonesian waters. IMIC is still unable to compete with other institutions that provide Information about Indonesia's maritime conditions, so IMIC must be able to increase the synergy of each stakeholder related to the marine sector.
\end{abstract}

\section{KEY WORDS}

Indonesia Maritime Information Centre (IMIC), national security, information warfare.

The latest developments are entering a digital era, making access to information easy to do and continuously adapted to every individual's needs in the world-the speed and ease that exists caused by the rapid development of information technology. In addition, the development of technology is also able to accommodate the pattern of people's lives that currently demand ease and speed in carrying out activities. It is not surprising that information becomes a daily necessity used in work, learning, entertainment, etc. Because information also provides benefits for humans to solve various problems faced in life (Unair.ac.id, 2020).

This information is built by a wide variety of data that is also obtained in a variety of ways. Information itself is a result of the processing of data into something meaningful to its recipients; Carlo Vercellis stated that "Information is the outcome of extraction and processing activities carried out on data, and it appears meaningful for those who receive it in a specific domain" (Vercellis, 2009, p. 7). At the same time, Safrudin Chamidi borrowed a definition from Ralston and Reilly that states that information is data and facts that are the result of an observation of natural phenomena, either in the form of writings or images equipped with a particular value (Chamidi, 2004, p. 314).

The result of the development of information fosters the belief that the war will change profoundly and permanently. New conflicts have been labeled "Cyberwar", "Information Warfare", "Network Centric Warfare", "Information Operations", and "Command \& Control Warfare" (Borden, 1999). Information warfare terms refer to information systems such as computers, communication networks, and databases, which are commonly used in military interests (Proborini, 2016 ). Information Warfare becomes one form of war without casualties that have the scope of command control and control over information. The ever-evolving technology also encourages the use of information technology tools such as viruses, worms, electromagnetic waves, ruffling opponent information systems, providing false information and damaging the installation of opponent information systems (Lewis, 2021).

This condition makes information a critical aspect that should be managed independently to support the country in realizing national security and avoiding these new 
wars. For Indonesia, which is one of the largest maritime countries in the world, the development of information and communication technology has affected the maritime domain and become a new threat in the domain; especially there is no official institution from the government that presents information about maritime affairs when it is very clear that information about maritime affairs will be the key in realizing maritime security for the country. Most of the information that can be accessed by the public is only sourced from the Central Bureau of Statistics (BPS). This condition is also exacerbated by the availability of information and data that is limited to economic and population aspects while maritime data and information have not been presented.

Therefore, the government, in this case, the Maritime Security Agency (Bakamla), created an agency that can provide information to the public both domestically and abroad that can be accessed through the website about maritime affairs. So far, observers and stakeholders who use the sea as objects, both from within the country and abroad using references or information from outside government institutions that are officially published to make the information sometimes biased and unfavorable for Indonesia because often the information is negative. This condition can also be interpreted as a sign that the threat of information warfare, especially in the maritime domain, is lurking in Indonesia.

To compensate for disproportionate maritime Information, Indonesia established a maritime information centre through the Maritime Security Agency (Bakamla) under the name Indonesia Maritime Information Centre (IMIC), which was inaugurated on July 22, 2020, by Kabakamla Laksdya Aan Kurnia (Lubabah, 2020). In addition to its function to respond to the information war that occurred, the establishment of IMIC is also the embodiment of Article 63 paragraph (1) letter c of Law No. 32 of 2014 on Marine, as well as Presidential Regulation No. 178 of 2014 on the Establishment of Maritime Security Agency followed up by SKB 8 ministries and Institutions on the exchange of data and information in the framework of law enforcement at sea. IMIC has a duty and role in making periodic reports in the form of weekly, monthly and yearly reports, as well as maritime publications that are likely to be needed in the future and will continue to be developed to support the interests of the government and public of Indonesia.

Looking at the background described above, this article will discuss IMIC's strategy in Information warfare related to Indonesia's vast sea area and strategic position. This study also aims to analyze and explore IMIC's ability to provide comprehensive maritime information and review IMIC's strategy in dealing with information warfare threats to realize Indonesia's national security. This article applies qualitative research methods with an explanatory approach. Thus research is conducted to find out why and how social phenomena occur among research variables and explain and identify patterns, themes related to research phenomena/ problems (Bandur, 2016, pp. 49-51). Meanwhile, data collection is conducted by literature studies of books, scientific journals, decision results, government laws and regulations, as well as sources derived from the internet (Bandur, 2016, p. 109) to analyze the subject of the research, namely ICMI's strategy in dealing with Information Warfare regarding Indonesia's sea areas that create a post-truth phenomenon or after truth that can create historical public anxiety about claims of truth from existing authorities (Harsin, 2018).

\section{RESULTS AND DISCUSSION}

Maritime information in maintaining National Security. Traditionally, security has been interpreted as a condition in which actors, in this case, are stateless, free from all forms of threats of danger, anxiety, and fear of physical threats, both military and nonmilitary originating from outside (Anggoro, 2003). Furthermore, Walter Lippmann stated that national security is a condition in which a nation is in a safe state as long as the government cannot be forced to sacrifice values that it considers vital and if it can avoid war or if it is forced to do so and come out victorious (Buzan, 1991, p. 432). The results of the researchers' observations show that Indonesia's condition as a maritime country is still not free from the circulation of marine information that is biased and disproportionate, so it has the potential to 
be a threat to Indonesia's maritime security, especially a study from the Edelman Trust Barometer institute in 2017 showed that public confidence in governments from other countries dropped by $41 \%$ (Harsin, 2018, p. 20) that shows that image improvement efforts made through IMIC will encounter severe obstacles.

Disproportionate circulation of information will certainly have an adverse effect on Indonesia, especially K.J. Holsti has emphasized that information is an important element of national security in addition to diplomacy capabilities, economic resilience and military strength (Aqlil, 2019, p. 13). Indonesia, which is in the Southeast Asia region, makes all conditions experienced by this region will provide spillover effect on Indonesia's security conditions. Moreover, Indonesia has an area of the sea reaching 3.25 million Km2 with a coastline length of $108,000 \mathrm{Km}^{2}$. These conditions make Indonesia have logical consequences of safeguarding Indonesia's seas by first understanding that the Indonesian state has a great responsibility to ensure its sea area remains safe so as to affect the wider security context.

The threat of information war to Indonesia is reflected in the widespread information circulating from foreign institutions that impressed Indonesia's position because it knows that Indonesia has a big role to play in the world's sea distribution channels (Sukarno, 2020). Please note that Indonesia has 4 out of 10 choke points or narrow straits that are used as international shipping lanes that are very prone to criminality; chokepoints are Malacca Strait, Sunda Strait, Lombok Strait, and Makassar Strait (Nurbaiti, 2020). The ease of information transfer supported by technological advances causes many parties who can easily learn how to conduct effective internet warfare attacks and disrupt Indonesia's defence conditions in the territorial waters.

Various Agencies in providing Maritime Information in Southeast Asia. To secure the sea area, Indonesia needs precise and up to date information about any events that occur within the sphere of sovereignty that has because widespread cynical perceptions, of course, also affect the trust of the international public. Domestically Indonesia is hampered by conditions where until 2020 alone, information coming from within the country about the sea conditions has not been appropriately presented, and Indonesia still depends on the source of data coming from other agencies abroad. Several institutions present maritime Information in Southeast Asia that becomes reference information for Indonesia, namely:

1. International Maritime Bureau (IMB):

IMB is an extraordinary non-profit division of the International Chamber Of Commerce (ICC) founded in 1981 to act as a focal point in the fight against all types of crime and malpractice in the maritime domain. It is the embodiment of resolutions A 504 (XII) (5) and (9) adopted on November 20 1981, by the International Maritime Organization (IMO). As an urging for governments, all stakeholders and organizations in the world to cooperate and exchange information with each other through IMB. The purpose of establishing this organization is to maintain and develop coordinated actions in the fight against maritime fraud. IMB has an MOU with the World Customs Organization (WCO) and is an observer with Interpol (ICPO). Imb's primary task is to protect the integrity of international trade by seeking fraud and malpractice, identifying and investigating fraud, discovering new criminal methods and trends, and highlighting other threats to world trade (ICC-CCS.org, 2021).

2. Information Fusion Center (IFC):

IFC is a body established on April 27 2009, as a regional maritime security centre located in the Changi Command and Control Centre (CC2C) and organized by the Republic of Singapore Navy (RSN). IFC aims to facilitate information sharing and collaboration between partner countries to enhance regional maritime security.

The IFC claims that over the past decade, the agency has been at the forefront of providing actionable information to signal responses by regional and international navies, coastguards and other maritime agencies to deal with threats and incidents that threaten maritime security such as piracy; sea robbery; maritime terrorism; illegal smuggling of goods; illegal fishing; and illegal human migration. IFC also functions as an open and inclusive platform that brings together multinational and inter-agency collaboration to solve maritime security issues together (MINDEF Singapore, 2019). 


\section{Regional Cooperation Agreement on Combating Piracy and Armed Robbery against} Ships in Asia Information Sharing Centre (ReCAAP ISC):

The ReCAAP cooperation agreement is the first regional intergovernmental agreement to promote and enhance cooperation against piracy and armed robbery of ships in Asia. The ReCAAP Agreement was launched in November 2006 with 14 Asian countries, including North, Southeast and South Asian countries. The ReCAAP agreement has 20 members from other regions such as Norway, the Netherlands, Denmark, and the United Kingdom from Europe, Australia, and the United States. Meanwhile, ReCAAP ISC became an established body in Singapore on November 29, 2006, and is considered to meet the criteria as a Center of Excellence for information sharing in the fight against piracy and armed robbery of ships at sea (ReCAAP.org, 2021).

Impact of Information presented by maritime agencies. All information presented can have both positive and negative effects that become the object. The information provided by these institutions often corner Indonesia and give rise to the phenomenon of post-truth from the international public, whereas sources, how to learn, measure, build, and inform the public (Harsin, 2018, p. 25) conducted by the actor without first coordinating on the Indonesian side.

The problem of errors in disinformation is indeed a phenomenon that is difficult to prove definitively. Still, one can assume that many political statements in this regard relate to Indonesia's ambiguous, misleading, or partially deliberate maritime conditions, is acceptable and generates a political, economic response by journalism and new businesses in factchecking and rumor-checking, which is why they can be understood literally as truth (Harsin, 2018 , p. 9) which is actually the embodiment of the phenomenon of post-truth that is very detrimental to Indonesia.

For example, one of the news that triggered problems for Indonesia is the Report from the IMB agency that marks some areas of Indonesian waters as red zones, as shown in the picture below:

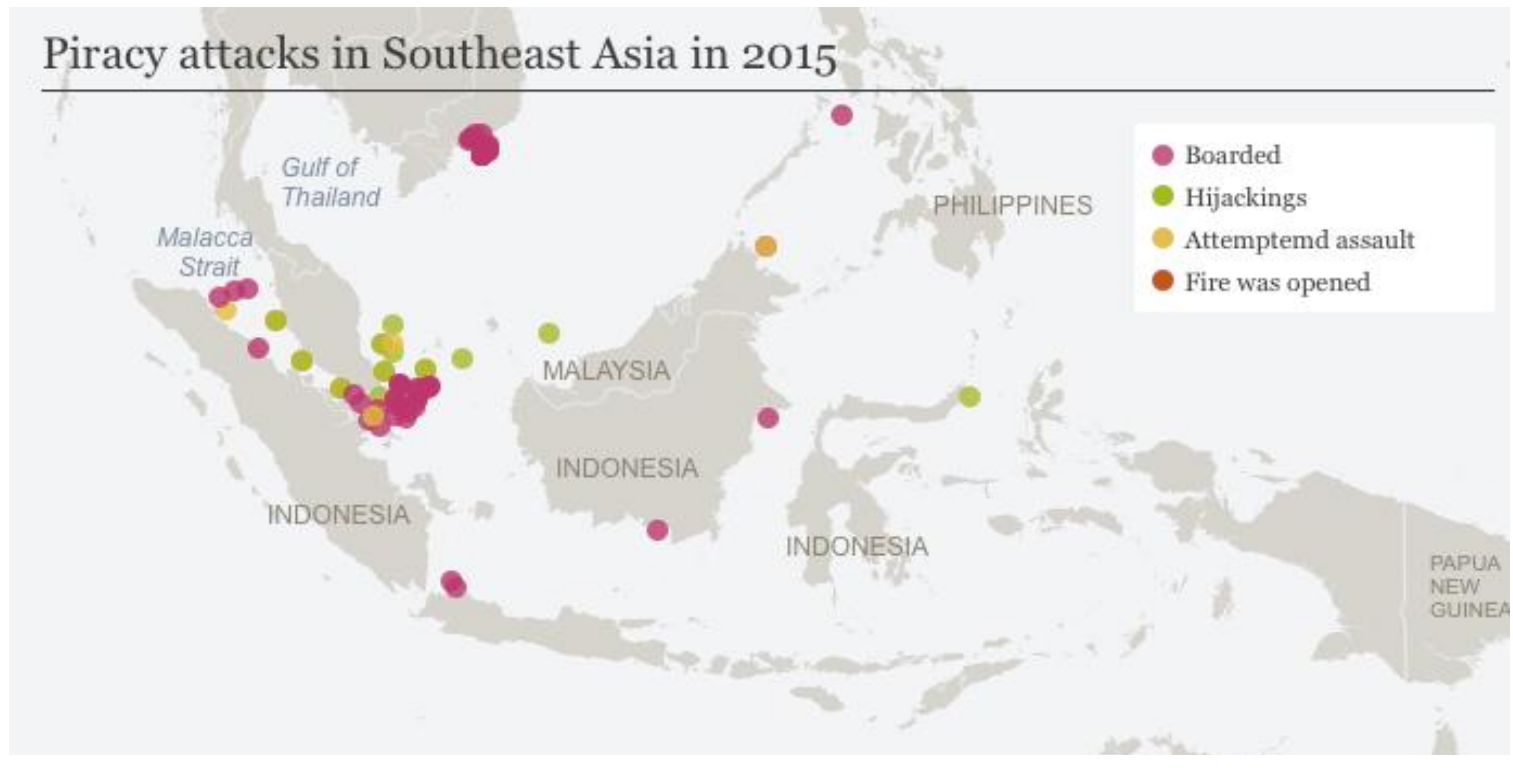

Figure 1 - Map of Piracy Attacks in Southeast Asia 2015-2020 (Source: ICC-CCS.org, 2021)

The Report makes global perceptions of Southeast Asia, especially Indonesia, negative. This is because the waters of the region are considered a paradise for pirates, especially the sea lanes off the state of Malacca, Singapore. The South China Sea is marked as one of the most commonly used areas for human trafficking in the region world. The labyrinthine conditions of the island and the labyrinthine link between the sea waters are considered to protect the pirates. They are exacerbated by allegations that the Indonesian navy is weak and corrupt to deal with the situation (Ebbighausen, 2016). This image is undoubtedly a problem that interferes with Indonesia's national security because indirectly, 
the published information violates Indonesia's principles and priorities in preventing threats. Analysis of maritime conditions that should serve to develop planning in policy formation, regulatory enforcement, and become the basis of national security (Holsti, 1972) instead it becomes a weapon used by other parties to corner Indonesia's position in the international sphere and become part of the information war as the application of destructive forces on a large scale to the assets and information systems of transportation critical infrastructure (Lewis, 2021) maritime affairs in the Indonesian region.

The dissemination of inaccurate information will have an impact on Indonesia's bargaining power and bargaining position globally. The condition requires Indonesia as a de facto ruler, and de jure has the legitimacy to request confirmation before the news about the events that occurred on Indonesian territory is transmitted to the international public. There is a logic that the security of aquatic areas, such as the Strait of Malacca, is within the grasp of coastal countries. However, the narrative issued by regional institutions such as IMB, IFC, and ReCAAP ISC often involves forces/countries outside the coastal countries of the Strait of Malacca and becomes an internationalization effort. The rejection of such involvement with the establishment of IMIC is the right step to be taken by Indonesia (Samudranesia, 2020) to avoid attacks that could jeopardize the country's national security and economy (Lewis, 2021).

The perspective of the United Nations Law of the Sea Convention (UNCLOS) 1982, specifically Article 17, stipulates that the Strait of Malacca is water used for international navigation. Ships passing through it, commercial vessels, fishing vessels and warships, enjoying the right of the innocent passage makes the security affairs of the region an exclusive responsibility of the security/defense authority of the Straits state and Indonesia should respond to cases of piracy that often occur in the Strait of Malacca recorded by IMB, IFC, and ReCAAP ISC (Samudranesia, 2020) with strategies conducted independently through IMIC in avoiding losses caused by reports of foreign institutions that often record ordinary theft as an act of piracy so that Indonesia is labeled as an unsafe country (Putra, 2020) moreover, modern society tends to react with active trust that makes the availability of information from foreign institutions credible without any confirmation of the data submitted (Harsin, 2018, p. 22). So the ability to provide or reject important information can be considered the pinnacle of strategic power for the country (Crawford, 2003, p. 2).

The tendency of other actors to focus on identifying and analyzing every element of Indonesia's territorial conditions will undoubtedly be a severe threat in the future, significantly when information warfare is echoed by other countries that currently control crucial Information (Crawford, 2003, p. 5) Indonesian waters. By prioritizing the source of information from third parties, existing information systems will be particularly vulnerable to some degree of interference or abuse in the future (Molander, et al., 1996, p. 8). At the same time, with the establishment of IMIC and the encouragement of resources to keep up with developments in cyberspace that are so dynamic as a way of building natural immunity to the threats that accompany these rapidly growing entities will be the most appropriate way for Indonesia to counter indirect attacks aimed at Indonesia through Information released by information centers based in other countries.

Specifically, the impact that may arise from the international declaration of Indonesian Waters as unsafe waters for shipping is multidimensional and includes political, sociocultural-economic, and defense and security. Wherefrom the Political dimension, the international community will argue that Indonesia is unable to guarantee the security of its National Waters; In the economic dimension, there will be a surge in shipping costs for ships passing through Indonesia and resulting in an increase in the price of goods and the value of goods insurance that can cause inflation; from the socio-cultural dimension, the international public will have the perception that many Indonesians rely on piracy as a source of income and become the habits or cultures of certain peoples in Indonesia; as well as from the defence and security dimensions, the insecurity of Indonesian waters causes major maritime countries to offer their military presence in Indonesian waters which will also cause problems of state sovereignty and territorial violations so that they are vulnerable to conflict. 
Problems in improving the capabilities of IMIC. As explained earlier, information about the insecurity of Indonesian waters will have an impact on the economic dimension because Indonesian waters are an international crossing of ships that want to sail to industrial areas in the region (Suwarno, et al., 2021, p. 65). The establishment of IMIC by Indonesia is intended to increase the capacity and capability of law enforcement through the support of valid and credible maritime information so that maritime vigilance and maritime deterrent in Indonesian waters can be increased (Mulyana, 2020). Some of the problems obtained from observations and interviews with several parties, among others:

1. Still do not have bank data on the maritime situation in the Indonesia region.

One of the supervisors of IMIC, Demo Putra of Bakamla, stated that the institution does not have a comprehensive picture of the maritime situation because the information is separated depending on the institution and the type of incident and the establishment of IMIC to integrate all Information in Indonesia and make operational planning based on data from each agency will make planning better because of the nature of the data is more comprehensive and accurate because it is analyzed by many agencies (John, 2020). This is also due to the number of institutions that have an interest in the Sea of Indonesia so that the data they have is not shared with other stakeholders.

2. Incomplete Infrastructure.

As a newly established Institution has become an informant for the completeness of infrastructure facilities. Therefore, Indonesia needs facilities and infrastructure in supporting information readiness and preparing appropriate counter-narratives to gain the trust of the international public. IMIC must be able to be responsible for Indonesia's territorial waters, which are predicted to cover $2 / 3$ of Indonesia's natural resources (SDA) that have not been entirely laid out and utilized optimally and well so that maritime security in the ASEAN regional region alone will bring up several countries to be parties seeking influence to be taken into account in the fields of politics, economy and defence and security.

3. The Information presented is incomplete.

The presentation of Information from IMIC, which is still a collection of news in print or electronic media, will also be one of the problems that hinder the development and effectiveness of this institution. Not to mention the fact that using existing news can be a weakness because the dissemination of such information is vulnerable to discredit and potentially detrimental to Indonesia (Harsin, 2018, p. 12).

4. Up to date data sources

The condition that IMIC still relies on news and information available from the media, the data obtained is relatively not up to date. This condition is exacerbated by the fact that the difficulties faced are also diverse such as the lack of interest from Malaysia to share data with IMIC automatically.

IMIC's strategy in information warfare. Liddell Hart states that strategy is "the art of distributing and applying resource means to fulfil the ends of policy" or the art of distributing and using the means at your disposal to realize the ultimate goal (Baylis \& Wirtz, 2007, p. 15). The statement is similar to that made by Andrew J. Good Paster, who suggests that "strategy covers what we should do (ends), How we should do it (ways), and what we should do it with (means)" (Nelson, 2016, pp. 243-244). From the statement, it can be considered that the essence of the strategy is a process in decision making that takes into account several main factors of a strategy on what to do by determining the objectives, objectives, objects and targets (ends), how to act by paying attention to the way it performs, its concepts, and methods (forms), and what to do using means, strengths, resources and potential (means). So that a strategy at least contains the above elements precisely and balanced. The following is a specific discussion on IMIC's strategy in dealing with information warfare in Indonesian territorial waters, which includes ends, ways, and means:

Ends (Goal) IMIC. Ends (target or final goal) IMIC is to enhance national security. These objectives are achieved through the tasks and functions of IMIC as a monitoring agency (surveillance), collecting \& fuse, processing (analysis purpose), sharing info (national \& regional), building maritime picture, create naval awareness, and provide an early detection system (Badan Keamanan Laut Repulik Indonesia , 2020, p. 4). The establishment 
of IMIC by Indonesia is also intended to increase the capacity and capabilities of law enforcement through the support of valid and credible maritime information so that navigational vigilance and maritime deterrents in Indonesian waters can be increased (Mulyana, 2020) through a national information centre that will be able to combine naval data \& information (Badan Keamanan Laut Republik Indonesia, 2020).

To achieve these goals, IMIC is supported by the organizational structure as shown in the picture below:

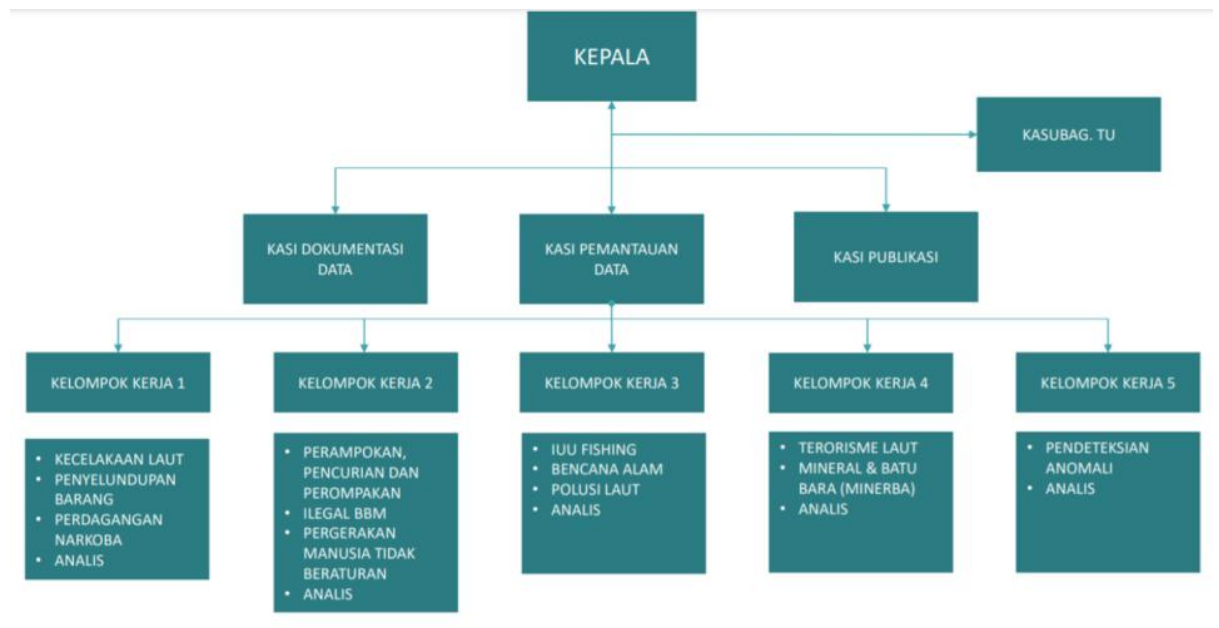

Figure 2 - Organizational Structure of IMIC

With this organizational structure, it is expected that IMIC benefits in supporting information for marine users, supporting law enforcement operations at sea, and supporting maritime studies (Badan Keamanan Laut Repulik Indonesia , 2020, p. 3) consideration in maritime policymaking will run optimally. The structure is also projected to be able to increase the capacity and capabilities of law enforcement in Indonesian waters, provide information support to maritime stakeholders, and confirm reports of other regional information agencies on Indonesia's naval condition while anticipating misinformation, fake news, rumors, and lies that can be voiced by other actors (Harsin, 2018, p. 9).

Ways (ordinances of action) IMIC. In fulfilling aspects of Ways, IMIC strives to integrate any data and information about Indonesian waters through Voluntary Community Report (VCR) established by IFC in 2010 (Badan Keamanan Laut Republik Indonesia, 2020, p. 12). This platform will undoubtedly benefit many, considering the shipping community can directly report incidents that interfere with marine safety or anomalous behavior at sea. IMIC has also followed the success of the IFC by encouraging merchant vessels sailing under any flag to report incidents or unusual behavior (ifc.org.sg, 2021) in Indonesian territorial waters in the Maritime Surveillance Community (MSC) (Badan Keamanan Laut Republik Indonesia, 2020, p. 14).

There are four stages in the mechanism of action of IMIC, namely: 1). Collecting data from various sources such as live information, online media news and others; 2). Validate by ensuring the information obtained is correct by coordinating with the relevant parties; 3 ). Verify all data and information collected by sending the data to relevant stakeholders for verification so that the data is more complete and accurate at the end of each month and last 4). Publish data and information as an overview of maritime conditions in the territory of Indonesia at a particular time (Badan Keamanan Laut Republik Indonesia, 2020, p. 6). At that stage, it is expected that misinformation, on the one hand, refers to the dissemination of inaccurate information that makes the public mistakenly think that the data is accurate. But on the other hand, it is also seen as a deliberate act to disseminate false or inaccurate information (Harsin, 2018, p. 10). 


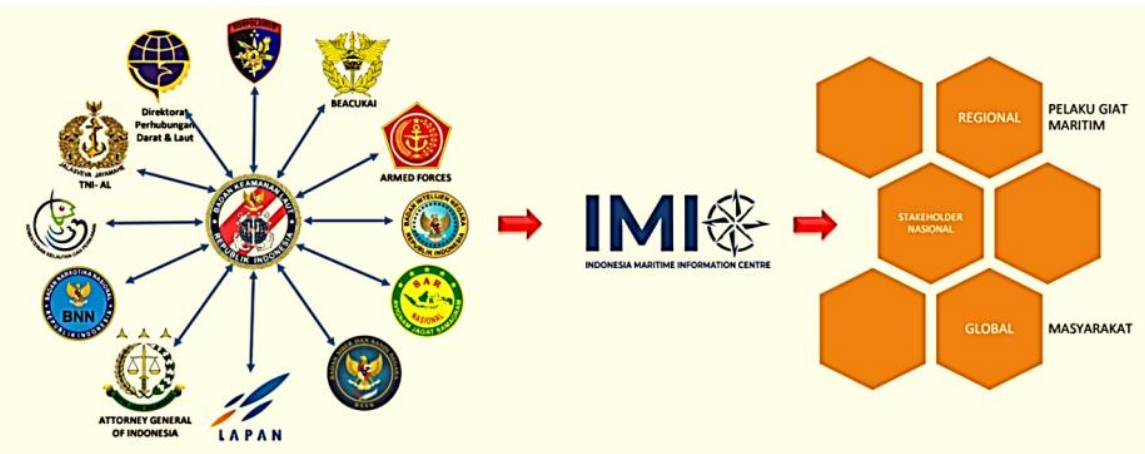

Figure 3 - Information Flow of IMIC

Source: (Badan Keamanan Laut Republik Indonesia, 2020, p. 7)

Furthermore, the coordination scheme conducted by IMIC by using facilities and infrastructures such as dashboard Bakamla and Google earth pro to see the fact of monitoring satellite imagery, Personal Computer and laptop, IMIC website servers, and social media Instagram and Youtube. Will generate a working pattern as shown below:

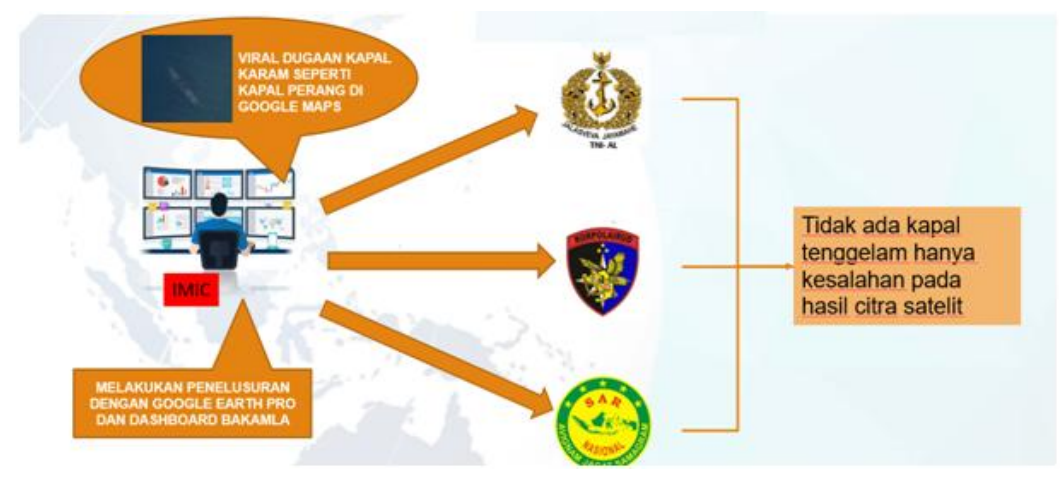

Figure 4 - IMIC Working Flow Example

Source: (Badan Keamanan Laut Republik Indonesia, 2020, p. 7)

Working flow or how IMIC collects and validates news will be more effective if it refers to the example shown where validation begins with IMIC obtaining viral information of suspected shipwrecks such as warships in sukabumi glasses of water recorded by google earth satellite imagery. After receiving the information, IMIC performs searches using bakamla dashboard app and Google earth pro to see the fact of monitoring the satellite imagery. However, to ensure such monitoring, IMIC coordinates with stakeholders close to the scene to then deploy the nearest Navy or POLAIR ship to conduct field checks. It was reported that no vessel sank at the site. Furthermore, Basarnas also noted that there was never a ship that sank in the area. Based on the monitoring and coordination, it was concluded that no vessel sank. The event is just an error in satellite imagery. This reporting scheme will undoubtedly show significant differences with the reporting of other agencies that will immediately provide updates on the sinking of ships in Indonesian waters.

From the illustration, it is not suggested that one of the supervisors of IMIC, Demo Putra of Bakamla, stated that foreign institutions do not have a comprehensive picture of the maritime situation because the information is separated depending on the institution and the type of incident. Furthermore, Putra added that the establishment of IMIC to integrate all information in Indonesia and make operational planning based on data from each agency will make planning better because of the nature of the data that is more comprehensive and accurate because it is analyzed by many agencies (John, 2020). From the statement can also be considered that the involvement of many parties will help the process of updating data by IMIC; the integration steps carried out will also be a strong bulwark in protecting critical information-based infrastructure (Lewis, 2021) regarding Indonesian waters so that 
the dissemination of information that is not following real conditions by authorities unrelated to the Indonesian government can be immediately addressed. However, it is undeniable that the boundaries between countries, as historically defined, are complicated by the interactions that develop in the information infrastructure. At least Indonesia can speed up the risk assessment process (Molander, et al., 1996, p. xviii) to avoid the threat of information warfare arising from the global maritime information flow as illustrated in the map below:

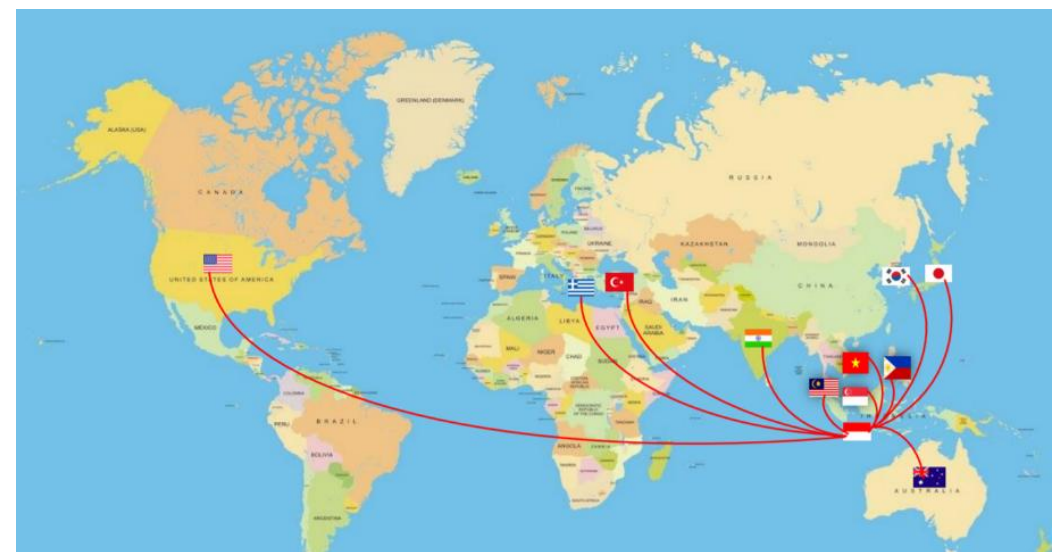

Figure 5 - Global Maritime Information Flow

Source: (Badan Keamanan Laut Republik Indonesia, 2020, p. 8)

From the statement can be considered that the involvement of many parties will help the process of updating data by IMIC; the integration will also be a strong fortress in protecting critical information-based infrastructure (Lewis, 2021) regarding Indonesian waters so that the dissemination of information that is not following actual conditions by authorities unrelated to the Indonesian government can be immediately addressed. However, it is undeniable that the boundaries between countries as historically defined are complicated by the interactions that develop in the information infrastructure. At least Indonesia can speed up the risk assessment process (Molander, et al., 1996, p. xviii) to avoid threats information warfare.

Means (facilities, strengths, resources, potentials) IMIC. As explained earlier, information about the insecurity of Indonesian waters will impact the economic dimension because Indonesian waters are an international crossing of ships that want to sail to industrial areas in the region (Suwarno, et al., 2021, p. 65). Therefore, Indonesia needs facilities and infrastructure in supporting information readiness and preparing appropriate counter-narratives to gain the trust of the international public. IMIC must be able to be responsible for Indonesia's territorial waters that are predicted to cover $2 / 3$ of Indonesia's territory with natural resources (SDA) that have not been entirely laid out and utilized optimally and well so that maritime security in ASEAN regional areas alone will bring up several countries to be parties seeking influence to be taken into account in the political, economic and defense and security fields. Thus, ensuring that disseminating information through various information and communication technology applications, including social media (Subejo, et al., 2021, p. 91), becomes a must for IMIC. There is no doubt that technologies such as Global Maritime Distress Security and Safety System (GMSS), AIS, $\mathrm{LRC}, \mathrm{RCS}, \mathrm{VMS}, \mathrm{GS}, \mathrm{MRCC}, \mathrm{RCC}$, up to portable $\mathrm{pH}$ meters as pollution monitoring devices in the waters will be required as part of infrastructure facilities in monitoring in various aspects of maritime affairs should be prepared independently by IMIC, to ensure that any information obtained is proven to be true.

Output IMIC includes periodic reports in the form of weekly, monthly, and yearly reports, as well as maritime publications that are needed in the future and will continue to be developed (Mulyana, 2020) and presentation of daily situation maps through IMIC News (Daily) containing the recapitulation of events at sea (Badan Keamanan Laut Repulik Indonesia , 2020, p. 10). It can be considered as part of IMIC's way of implementing a 
strategy to take control of information related to Indonesia's maritime domain. This method can at the same time accommodate the interests of other actors such as research institutions and domestic and foreign mass media so that the sources of information referred to by these institutions can be ascertained validity and will not be a nuisance to the interests and national security of Indonesia. With a large target intended, IMIC also has a solid organizational aspect, so it appears that the planned operational activities can be executed carefully. IMIC needs to continuously improve the capacity and quality of human resources (HR) involved through a series of coaching and training conducted by involving stakeholders who have experience managing information, especially within the framework of IMIC Maritime Education.

IMIC, as an institution that has the ultimate goal of improving maritime security and making Indonesia's seas free from threats of violence, navigational threats, threats to the environment and marine resources, as well as the threat of violations of the law, need to overcome the high fragmentation of national law enforcement authorities that often weaken control and surveillance efforts in Indonesian territorial waters. Furthermore, the Indonesian government also needs to establish strict regulations on integrating all information so that maritime stakeholders who have the latest news will always report the latest data they obtain without any obstacles. IMIC can also replicate the preparedness of the United States supported by the concept of minimum essential information infrastructure (MEII), supported by a consistent feasibility assessment. So the potential for profit or loss due to the availability of the correct information at the right time can be a differentiator in determining success or failure in the modern political arena (Crawford, 2003, p. 3).

\section{CONCLUSION}

A strategy is a decision-making process against the main elements that include Ends (target or final goal) to improve national security, Ways (procedures to act) by integrating into collecting information about Indonesian waters, and Means (facilities, strength, resources, potentials owned) by preparing human resources and infrastructure needed in supporting the provision of information that can offset information from other institutions. It was making IMIC take over the role of other institutions in the region that inform data and facts about the condition of Indonesian waters. However, limited resources, especially economic support in preparing facilities and infrastructure, will be significant obstacles that overshadow the realization of the strategy. Decreasing information on the extent of violations of sovereignty and law in Indonesian waters by presenting precise credible details will affect the level of trust of the international community, especially for those who take advantage of Indonesia's waterways.

The advantages of Indonesia's strategic and profitable geographical position in terms of geo-economics, geopolitical and geostrategic, although making the activity and frequency of sailing across the waters within the Indonesian National Jurisdiction will continue to increase and increase Indonesia's insecurity and vulnerability to threats to the environment, natural resources and national maritime security of Indonesia. This is where IMIC, as a marine information centre, can show their role to realize national security and even transform Indonesia's marine condition as one of the aspects that can encourage Indonesia's national welfare and development. IMIC should increase the synergy of every stakeholder related to maritime affairs to empower this Maritime Security Information Center to the maximum. National Security, which refers to the nation's ability to protect its national values against threats, is an impossible achievement if IMIC is unable to prepare reliable human resources to accommodate the data obtained and package it according to the needs of Indonesian water users.

\section{REFERENCES}

1. Anggoro, K., 2003. Keamanan Nasional, Pertahanan Negara, and Ketertiban Umum. Denpasar, Departemen Kehakiman and HAM RI, p. 1. 
2. Aqlil, F., 2019. Jepang sebagai Non Nuclear Weapon State dalam Non Proliferation Treaty (NPT). Padang: Universitas Andalas.

3. Badan Keamanan Laut Republik Indonesia, 2020. Kolaborasi IMIC and INSA, Jakarta: Badan Keamanan Laut Repulik Indonesia.

4. Badan Keamanan Laut Repulik Indonesia, 2020. Kolaborasi IMIC and INSA, Jakarta: Badan Keamanan Laut Repulik Indonesia.

5. Bandur, A., 2016. Penelitian Kualitatif: Metodologi, Desain, and Teknik Analisis Data dengan NVlivo 11 Plus. Jakarta: Mitra Wacana.

6. Baylis, J. \& Wirtz, J., 2007. Strategy in the Contemporary World. Oxford: Oxford University Press.

7. Borden, A., 1999. What is Information Warfare? [Online] Available at: https://www.airuniversity.af.edu/Portals/10/ASPJ/journals/Chronicles/borden.pdf

8. Buzan, B., 1991. New patterns of global security in the twenty-first century. International affairs 67 (3), pp. 431-451.

9. Chamidi, S., 2004. Kaitan antara Data and Informasi Pendidikan". Jurnal Pendidikan and Kebudayaan (48), pp. 311-328.

10. Crawford, G. A., 2003. Information Warfare: New Roles For Information Systems in Military Operations, San Fransico: Chronicles.

11. Defence Education Enchancement Programme, 2017. Media-(Dis)Information-Security, Brussels: NATO.

12. Ebbighausen, R., 2016. Southeast Asia - a pirates' paradise. [Online] Available at: https://www.dw.com/en/southeast-asia-a-pirates-paradise/a-18599742

13. Harsin, J., 2018. Post-Truth and Critical Communication. Oxford Research Encyclopedia, Communication, pp. 1-36.

14. Holsti, K., 1972. International politics: a framework for analysis. Englewood Cliff: Prentice-Hall.

15. ICC-CCS.org, 2021. International Maritime Bureau. [Online] Available at: https://www.icc-ccs.org/icc/imb

16. ifc.org.sg, 2021. VCR FAQ. [Online] Available at: https://www.ifc.org.sg/ [Accessed 7 Juli 2021].

17. John, J., 2020. Indonesia's new intelligence hub drawing on data in the war on illegal fishing. [Online] Available at: https://www.eco-business.com/news/indonesias-newintelligence-hub-drawing-on-data-in-the-war-on-illegal-fishing/

18. Lewis, B. C., 2021. Information Warfare. [Online] Available at: https://fas.org/irp/eprint/snyder/infowarfare.htm

19. Lubabah, R. G., 2020. Kepala Bakamla Resmikan Pusat Informasi Maritim Indonesia. [Online] Available at: https://www.merdeka.com/peristiwa/kepala-bakamla-resmikanpusat-informasi-maritim-indonesia.html

20. MINDEF Singapore, 2019. Fact Sheet on Information Fusion Centre (IFC) and Launch of IFC Real-Time Information-Sharing System (IRIS). [Online] Available at: https://www.mindef.gov.sg/web/portal/mindef/news-and-events/latest-releases/articledetail/2019/May/14may19_fs

21. Molander, R. C., Riddile, A. S. \& Wilson, P. A., 1996. STRATEGIC INFORMATION WARFARE: A New Face of War. Santa Monica: RAND.

22. Mulyana, C., 2020. IMIC Tingkatkan Keamanan and Keselamatan Laut. [Online] Available at: https://mediaindonesia.com/politik-dan-hukum/330868/imic-tingkatkankeamanan-dan-keselamatan-laut

23. Nelson, C. R., 2016. The Life and Work of General Andrew J. Goodpaster. New York: Rowman \& Littlefield.

24. Nurbaiti, 2020. Choke Point and Major Strait: Geopolitik-Geoekonomi-Geostrategi Indonesia. [Online]

25. Proborini, D., 2016. Sisi Gelap Era Informasi: Information Warfare and Perang Virtual. Jurnal Globalisasi and Masyarakat Informasi, pp. 1-6.

26. Putra, N. P., 2020. Rilis Akhir Tahun 2020, Bakamla Pamerkan IMIC untuk Seimbangkan Pemberitaan Asing. [Online] Available at: 
https://www.liputan6.com/news/read/4445319/rilis-akhir-tahun-2020-bakamla-pamerkanimic-untuk-seimbangkan-pemberitaan-asing

27. ReCAAP.org, 2021. About ReCAAP Information Sharing Centre |combating maritime robbery, sea piracy. [Online] Available at: https://www.recaap.org/about_ReCAAP-ISC

28. Samudranesia, 2020. Ini Catatan untuk IMIC, Pusat Informasi Ala Bakamla. [Online] Available at: https://samudranesia.id/ini-catatan-untuk-imic-pusat-informasi-ala-bakamla/

29. Subejo, et al., 2021. Strategi Komunikasi and Pemanfaatan Teknologi Informasi and Komunikasi Dalam Pengembangan Ketahanan Desa Wisata Pada Masa Pandemi Covid-19 Di Cirebon. Jurnal Ketahanan Nasional Vol.27 No.1, pp. 90-111.

30. Sukarno, P. A., 2020. Namarin: Rencana Bakamla Dirikan IMIC Berpotensi Ganggu Diplomasi. [Online]

Available at: https://ekonomi.bisnis.com/read/20200628/98/1258728/namarin-rencana-bakamladirikan-imic-berpotensi-ganggu-diplomasi

31. Suroyo, 2012. Teori Strategi,. Jakarta: Lembaga Ketahanan Nasional RI.

32. Suwarno, P., Sumantri, S. H. \& Bahar, F., 2021. Rekonstruksi Keamanan Maritim Indonesia Dalam Rangka Mewujudkan Ketahanan Wilayah (Studi Di Kabupaten Natuna Periode Tahun 2019-2020). Jurnal Ketahanan Nasional Vol.27 No.1, pp. 65-89.

33. Unair.ac.id, 2020. Faktor-Faktor Penyebab Adanya Kebutuhan Informasi. [Online] Available at: http://dip.fisip.unair.ac.id/id_ID/faktor-faktor-penyebab-adanya-kebutuhaninformasi/

34. Vercellis, C., 2009. Bussines Intelligence: Datamining and Optimization for Decision Making. Hoboken: Wiley and Sons. 